\title{
Translation and adaptation into Brazilian Portuguese of the Family Accommodation Scale for Obsessive- Compulsive Disorder - Interviewer-Rated (FAS-IR)
}

\author{
Tradução e adaptação para o português do Brasil da Escala de Acomodação Familiar \\ - Pontuado pelo Entrevistador (FAS-IR)
}

\author{
Juliana Braga Gomes, ${ }^{1}$ Lisa Calvocoressi, ${ }^{2}$ Barbara Van Noppen, ${ }^{3}$ Michele Pato, ${ }^{4}$ Elisabeth Meyer, ${ }^{5}$ Daniela \\ Tusi Braga, ${ }^{6}$ Christian Haag Kristensen, ${ }^{7}$ Aristides Volpato Cordioli ${ }^{8}$
}

\begin{abstract}
${ }^{1}$ Mestranda em Ciências Médicas: Psiquiatria, Universidade Federal do Rio Grande do Sul (UFRGS), Porto Alegre, RS, Brazil. ${ }^{2}$ PhD. Department of Epidemiology and Public Health, Yale University School of Medicine, New Haven, CT, USA. ${ }^{3}$ PhD. Keck School of Medicine, Department of Psychiatry, University of Southern California, Los Angeles, CA, USA. ${ }^{4}$ MD. Keck School of Medicine, Department of Psychiatry, University of Southern California. ${ }^{5}$ Doutora em Psiquiatria, UFRGS. ${ }^{6}$ Doutoranda em Ciências Médicas: Psiquiatria, UfRGS. ${ }^{7}$ Doutor. Professor, Pontifícia Universidade Católica do Rio Grande do Sul (PUCRS), Porto Alegre, RS, Brazil. ${ }^{8}$ Doutor, Professor associado, Departamento de Psiquiatria e Medicina Legal, UFRGS.
\end{abstract}

Financial support: Fundo de Incentivo a Pesquisa e Eventos (FIPE).

\begin{abstract}
Objective: To describe the process of translation and adaptation into Brazilian Portuguese of the Family Accommodation Scale for ObsessiveCompulsive Disorder - Interviewer-Rated (FAS-IR).

Method: The process of translation and adaptation of the scale involved four bilingual health professionals. The scale was initially translated into Brazilian Portuguese independently by two professionals. Then, the two versions were compared, resulting in a preliminary Portuguese version that was administered to 15 relatives of patients diagnosed with obsessive-compulsive disorder (OCD) with different education levels, deliberately chosen to collect language adjustment suggestions. Subsequently, the scale was translated back into English independently by two other professionals. After comparing the two back translations, a new English version was generated. This version was reviewed and approved by the authors of the original scale.

Results: The Brazilian Portuguese version of the FAS-IR proved to be easily understood and can be used in relatives of OCD patients from different socioeconomic backgrounds.

Conclusion: Adaptation of the FAS-IR into Brazilian Portuguese will enable health professionals to assess the level of accommodation in relatives of OCD patients and allows the development of future studies aimed at 1) studying the influence of family accommodation on maintaining and possibly facilitating OCD symptoms, and 2) assessing the effect of family accommodation on treatment outcomes in Portuguese-speaking populations.

Keywords: Obsessive-compulsive disorder, family relations, questionnaires, translation.
\end{abstract}

\section{Resumo}

Objetivo: Descrever o processo de tradução e adaptação para o português do Brasil da Family Accommodation Scale for Obsessive-Compulsive Disorder - Interviewer-Rated (FAS-IR).

Método: O processo de tradução e adaptação da escala envolveu quatro profissionais de saúde bilíngues. A escala foi inicialmente traduzida de forma independente para o português do Brasil por dois profissionais. A seguir, as duas versões foram comparadas, resultando em uma versão inicial em português que foi aplicada a 15 familiares de pacientes com transtorno obsessivo-compulsivo (TOC), com diferentes níveis de instrução, deliberadamente escolhidos para coletar as sugestões de ajuste linguístico. Subsequentemente, a escala foi retrotraduzida independentemente por outros dois profissionais da saúde. Depois de comparar as duas retrotraduções, uma nova versão da escala foi gerada em inglês. Essa versão foi revisada e aprovada pelos autores da escala original.

Resultados: A versão em português do Brasil da escala FAS-IR mostrou ser facilmente compreendida e pode ser usada em familiares de pacientes com TOC de diferentes níveis socioeconômicos.

Conclusão: A FAS-IR adaptada ao português do Brasil fará com que profissionais de saúde possam avaliar o nível de acomodação em familiares de pacientes com TOC e permitirá a realização de futuros estudos com os objetivos de 1) estudar a influência da acomodação familiar na manutenção e, possivelmente, na facilitação dos sintomas do TOC e 2) examinar o efeito da acomodação familiar sobre os resultados do tratamento em populações de países de língua portuguesa.

Descritores: Transtorno obsessivo-compulsivo, relações familiares, questionários, tradução (processo).

Correspondência:

Juliana Braga Gomes, Av. Iguaçu, 165, sala 506, Bairro Petrópolis, CEP 90470-430, Porto Alegre, RS, Brazil. Tel.: +55 (51) 9808.9708. E-mail: ju_gomes@terra.com.br No conflicts of interest declared concerning the publication of this article.

Copyright $(\odot$ Revista de Psiquiatria do Rio Grande do Sul - APRS

Submitted Jun 16, 2010. Accepted Jun 22, 2010. 


\section{Introduction}

Obsessive-compulsive disorder (OCD) is characterized by recurrent intrusive thoughts (obsessions) which increase the individual's anxiety, typically accompanied by the urge to perform neutralizing overt or covert actions (compulsions), which are associated with decreased anxiety. These symptoms cause significant distress and interfere with the patient's daily routine. ${ }^{1}$ Questions have been asked about the family's influence on obsessive-compulsive (OC) symptoms. In fact, studies have shown a 4-5 times greater incidence of OCD in relatives of OCD patients and a high concordance of the disorder in twins, pointing to the presence of genetic factors. Studies assessing twins and families have supported the hypothesis that OCD is a disorder of familial incidence, and genetic factors have been shown to play a significant role in the expression of the disorder. ${ }^{2}$ A meta-analysis was conducted with a sample of 1.209 first-degree relatives of OCD patients and found that the risk of developing the disorder was four times higher than in relatives of controls ( 8.2 vs. $2 \%){ }^{3}$

Environmental factors, including family responses to the disorder, may contribute to maintaining or facilitating OCD symptoms. Family accommodation refers to the participation of family members in rituals, the modification of personal and family routines, facilitation of avoidance behavior, and taking on the patient's responsibilities. ${ }^{4}$ Calvocoressi et al. ${ }^{5}$ reported that family accommodation behaviors were present in $88 \%$ of spouses or parents of patients with OCD and was significantly correlated with patient symptom severity, global functioning, family dysfunction, and relatives' stress. Excessive accommodation of relatives to compulsions may undermine exposure-based therapy, perpetuate and reinforce symptoms, and increase the relatives' distress feelings. ${ }^{6}$ However, little is known about how family accommodation affects the severity and maintenance of OCD symptoms, or how a change in family accommodating behaviors may contribute to the patient's improvement or adherence to ongoing treatment. An instrument developed by Calvocoressi et al., ${ }^{4,5}$ namely, the Family Accommodation Scale for Obsessive-Compulsive Disorder - Interviewer Rated (FAS-IR), has been used in several clinical studies to assess family accommodation and improve our understanding of this topic.

In 1995, Calvocoressi et al. ${ }^{4}$ conducted an open trial with 34 relatives of OCD patients to analyze the frequency and nature of family accommodation and the consequences of family members refusing to participate in the patient's rituals. The authors found that most families participated in compulsions and took on responsibilities that would be the patient's, i.e., family members accommodated the patient's symptoms. In that study, the authors developed a pilot questionnaire to assess the level of family accommodation among relatives of patients with OCD.
Later, in 1999, Calvocoressi et al. $^{5}$ assessed the psychometric properties of a revised version of the same instrument. The results of this second study were consistent with those of the previous one ${ }^{4}$ : of the 32 families whose members accommodated the patient's symptoms, $84 \%$ reported patient anxiety, $66 \%$ indicated that the patients expressed anger, and $75 \%$ reported that the patients spent more time completing rituals whenever the relatives did not accommodate the patient's demands. Most relatives did not associate accommodation with an improvement in symptoms or patient functioning; nevertheless, most of the relatives confirmed that they accommodated OCDrelated demands, often compromising their own and the family's functioning. These findings suggest that many relatives would probably be receptive to interventions specifically designed for relatives of OCD patients, such as psychoeducation, in order to reduce family stress and develop more functional ways of responding to OC symptoms. ${ }^{5}$

The FAS-IR is a clinician-administered, validated scale comprises two parts: the first part is a checklist which assesses the symptoms of OCD patients; the second part consists of 12 items that assess the level of family accommodation in different dimensions of accommodation. The scale should be administered by a trained professional to an identified relative of the OCD patient who spends at least one hour every day face to face with the patient.

Family accommodation has been identified as a robust contributor to predicting OCD symptom severity, as recently reported by Van Noppen \& Steketee. ${ }^{7}$ In a series of pathway analyses, those authors identified that family accommodation made the largest, most significant contribution to OCD symptom severity in both patient-rated and relative-rated measures of perceptions of family responses. Accordingly, the strongest determinant of family accommodation was a relative's assessment of the degree of control the patient had over their behavior. Although we are still trying to understand what exactly drives relatives to accommodate, it is clear that family accommodation has negative effects on OCD patients and their families.

In a study conducted in Brazil, Ferrão et al..$^{8}$ evaluated the phenomenon of family accommodation and observed that relatives of refractory patients presented higher rates of accommodation and exhaustion when compared to relatives of patients who responded to treatment. These results demonstrate the relevance of the FAS-IR ${ }^{4,5}$ as a sensitive outcome measure.

However, in order to better and more consistently assess family accommodation in different populations, translation of the scale into different languages, including Brazilian Portuguese, is required. Therefore, the objective of our study was to describe the translation and adaptation into Brazilian Portuguese of the FAS-IR, developed by Calvocoressi et al. ${ }^{5}$ 


\section{Methods}

After receiving authorization from the authors of the original scale (Calvocoressi L, 2007, personal communication), two independent professionals translated and adapted the scale into Brazilian Portuguese. Based on the two translations, a preliminary version of the instrument was developed and administered to 15 relatives of OCD patients. Subjects were selected to represent different socioeconomic levels and cultural backgrounds. The aim of this pilot questionnaire administration was to assess the quality of the translation and to collect suggestions for language adjustments aimed at improving instrument clarity and ensuring that the items would be easily understood by groups from different cultural and socioeconomic backgrounds. The pilot questionnaire was administered at Hospital de Clínicas de Porto Alegre (HCPA), Porto Alegre, RS, Brazil. Each interview lasted for approximately 1 hour. Whenever the subject had difficulties understanding a question or a particular word, the interviewer reworded it until the respondent understood the meaning the interviewer wished to convey. The most frequent suggestions made by the interviewees were either added to the questionnaire in parentheses or used to rephrase the questions, to ensure their understanding in a definitive version.

Once the scale was considered to be appropriately translated into Portuguese, its back-translation into English was conducted independently by two other bilingual health professionals who had not seen the instrument in its original form. After comparing the two back-translations, a new English version of the scale was generated. This version was reviewed and approved by the authors of the original scale. The final translated version of the FAS-IR is presented in Appendix 1. Figure 1 presents a flowchart of the process of translation, adaptation and back-translation.

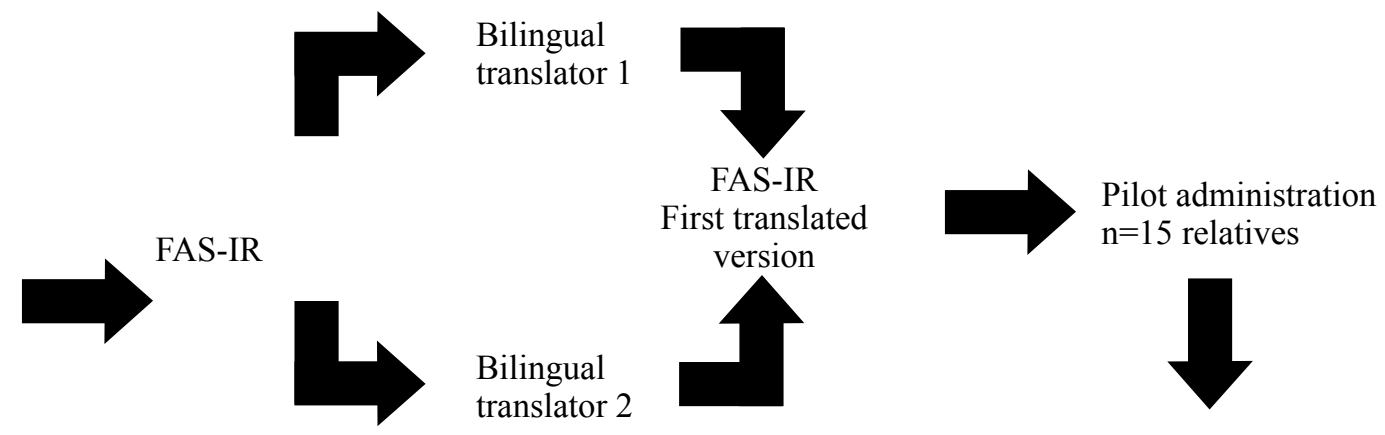

Language adjustments

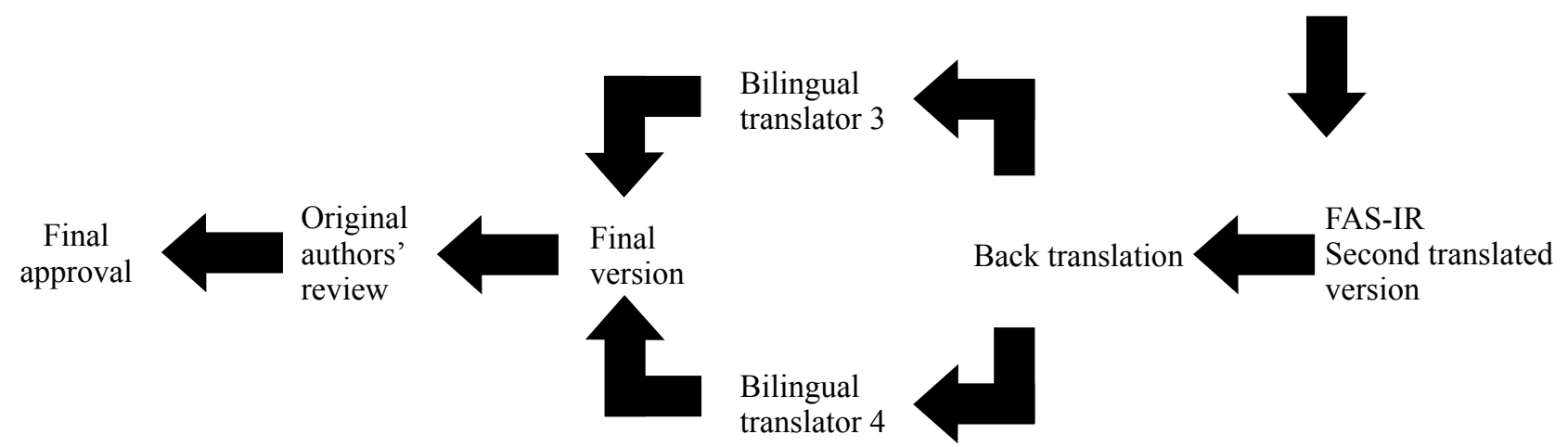

Figure 1 - Flowchart showing the steps involved in the translation, adaptation and back-translation of the Family Accommodation Scale for Obsessive-Compulsive Disorder - Interviewer-Rated

\section{Results}

Of the 15 relatives involved in the pilot questionnaire application, $93 \%$ were female and $53 \%$ were mothers of the patients; mean age was $55 \pm 16.4$ years. The participants had different education levels, ranging from $33 \%$ who had completed basic education to $7 \%$ with university degrees. As previously mentioned, some family members had questions about the wording of some questions; these subjects requested an explanation from the interviewer and made suggestions to improve the clarity and understanding of the instrument. The change made to the scale are listed in Table 1. 
Table 1 - Sources of difficulty and changes made to the scale item during and after the adaptation process

\begin{tabular}{lll}
\hline Prior to adaptation & Suggestions made by relatives & After adjustment \\
\hline The purpose of this interview & The reason for this interview & The purpose (reason) of this interview \\
Harming obsessions & Obsessions with bad things & Obsessions with aggressive content \\
Asbestos & Poisons & Asbestos (poisons) \\
Thoughts of incest & Sexual intercourse with relatives & Thinking of having sex with close relatives \\
Symmetrical & Perfect & Symmetrical (perfect) \\
Clothing organized alphabetically & Clothes organized by color & Clothing organized alphabetically and/or by color \\
Inanimate objects & Immovable, lifeless objects & Inanimate (lifeless) objects \\
Disturbance of inertia & Standing still & Disruption of inertia (standing still) \\
Pathological doubt & Excessive doubt & Pathological (excessive) doubt \\
Adjusting furniture & Arrangement of furniture in the house & Arrangement of furniture in the house \\
Providing reassurance & Showing confidence, reassured & Providing reassurance (showing confidence, reassuring) \\
Deliberately & Spontaneously, intentionally & Deliberately (intentionally) \\
Avoided topics of conversation & Avoided talking about some things & Avoided talking about some things \\
Check the burners on the stove & Check the stove burners & Check the stove burners \\
\hline
\end{tabular}

\section{Discussion and conclusion}

Throughout the process of adaptation of the FAS-IR into Brazilian Portuguese, we sought to achieve semantic equivalence between the original and the translated versions. This process involved using language with a focus on maintaining the meaning of the concepts contained in the original instrument so that it would have a similar effect on the respondents in both cultures. ${ }^{9}$ As a result, the interaction between subjects and interviewers was especially important, in the sense of enduring that the original meaning of the question would be conveyed. The process of adapting an instrument is thus a combination of literal word translation and careful fine-tuning that addresses the cultural context and lifestyle of the target population. ${ }^{9}$ Moreover, approval of the back-translated version by the original authors ensured that the original meanings were not lost. As a result, we strongly believe that the Brazilian version of FAS-IR can provide a baseline measure of accommodation and serve as a sensitive measure of changes obtained with cognitive-behavioral treatment approaches.

In sum, the availability of the FAS-IR in Brazilian Portuguese will allow Brazilian investigators to evaluate the participation of family members in rituals and changes in routine, as well as the influence of such participation on the maintenance of symptoms. Moreover, it can be used to assess whether family accommodation is a predictor of the treatment outcome. Finally, the translation of the FAS-IR will also enable comparisons between national and international studies on family accommodation.

Future studies are needed to assess the reliability and validity of the Brazilian version of the scale. Moreover, it would be interesting to add a family-based intervention, aimed at reducing family accommodation, to standard OCD treatments and examine whether this improves treatment outcomes.

\section{Acknowledgments}

The authors are grateful to health professionals Anna Williams, Patricia Pranke, Ygor Ferrão, and Rui Ramos Neto, and to all the patients and their relatives for their cooperation. Also our thanks to Esperança Moniz, at the University of Southern California, for her assistance with the back translation from Portuguese into English.

\section{References}

1. American Psychiatric Association. Manual diagnóstico e estatístico de transtornos mentais (DSM-IV-TR). $4^{\mathrm{a}}$ ed. Porto Alegre: Artmed; 2002.

2. Gonzales $\mathrm{CH}$. Aspectos genéticos do transtorno obsessivo-compulsivo. Rev Bras Psiquiatr. 2001;23(supl 2):38-41.

3. Hettema JM, Neale MC, Kendler KS. A review and meta-analysis of genetic epidemiology of anxiety disorders. Am J Psychiatry. 2001;158(10):1568-78.

4. Calvocoressi L, Lewis B, Harris M, Trufan BS, Goodman WK, McDougle CJ, et al. Family accommodation in obsessive compulsive disorder. Am J Psychiatry. 1995; 152:441-3.

5. Calvocoressi L, Mazure CM, Kasl SV, Skolnick J, Fisk D, Vesgo SJ, et al. Reliability and validity of the family accommodation scale for obsessivecompulsive disorder. J Nerv Ment Dis. 1999;187:636-42.

6. Steketee G, Van Noppen B, Lam J, Shapiro L. Expressed emotion in families and the treatment of obsessive compulsive disorder. In Session: Psychotherapy in Practice. 1998;4(3):73-91.

7. Van Noppen B, Steketee G. Testing a conceptual model of patient and family predictors of obsessive compulsive disorder (OCD) symptoms. Behav Res Ther. 2009; 47:18-25.

8. Ferrão YA, Shavitt RG, Bedin NR, de Mathis ME, Lopes AC, Fontenelle LF, et al. Clinical features associated to refractory obsessive-compulsive disorder. J Affect Disord. 2006;94(1-3):199-209.

9. Reichenheim EM, Moraes CL. Operacionalização de adaptação transcultural de instrumentos de aferição usados em epidemiologia. Rev Saude Publica. 2007;41(4):665-73. 
Anexo

\title{
ESCALA DE ACOMODAÇÃO FAMILIAR PARA TRANSTORNO OBSESSIVO-COMPULSIVO PONTUADO PELO ENTREVISTADOR (FAS-IR)
}

\author{
Desenvolvido por: \\ Lisa Calvocoressi, PhD, Carolyn M. Mazure, PhD, Barbara Van Noppen, PhD, Michele Pato, MD, e Lawrence H. Price, MD \\ Traduzida e adaptada por: \\ Juliana Gomes, Elisabeth Meyer, Daniela Braga, Christian Kristensen e Aristides Cordioli
}

Nome:

Relação de parentesco:

Entrevistador:

Data: . .

\section{INSTRUCÕES GERAIS PARA O FAMILIAR:}

"O propósito (motivo) desta entrevista é verificar as maneiras como você pode estar modificando seus comportamentos ou rotinas para acomodar os sintomas do(a) (nome do paciente). Durante esta entrevista, eu vou primeiramente perguntar sobre os sintomas obsessivo-compulsivos que o(a) (nome do paciente) tem apresentado, e depois vou perguntar sobre a maneira como você reage a esses sintomas.

Esta entrevista vai durar aproximadamente 30 minutos. Se, durante a entrevista, em qualquer momento, você não tiver certeza sobre o que eu estou perguntando a você, por favor, me fale, e eu tentarei esclarecer a questão para você."

\section{RELATÓRIO DO FAMILIAR SOBRE OS SINTOMAS DO PACIENTE}

INSTRUÇÕES PARA O FAMILIAR: “Eu vou definir obsessões, compulsões e outros sintomas relacionados ao TOC, e vou perguntar se o(a) (nome do paciente) tem apresentado algum desses sintomas durante a última semana."

(Leia a descrição de cada sintoma, marque todas as que se aplicam, e então peça que o familiar descreva os sintomas especificos do paciente. Anote os sintomas especificos na folha intitulada LISTA DE SINTOMAS DO PACIENTES (p. 4).)

\section{OBSESSÕES}

"Obsessões são ideias acompanhadas de aflição, pensamentos, imagens ou impulsos que entram na mente da pessoa de forma repetida e parecem ocorrer contra a sua vontade. Os pensamentos podem ser repugnantes ou assustadores, ou podem parecer sem sentido para a pessoa que os experimenta.

Agora vou revisar a lista dos diferentes tipos de obsessões comuns ao TOC. Por favor, me diga se o(a) (nome do paciente) apresentou alguma dessas obsessões durante a última semana."

\section{OBSESSÕES DE CONTEÚDO AGRESSIVO}

"Durante a última semana, o(a) (nome do paciente) experimentou obsessões envolvendo medo de machucar a si próprio ou a outros, roubar coisas, dizer impulsivamente obscenidades ou insultos, agir sob impulsos indesejados ou fazer algo que cause embaraço? $\mathrm{O}(\mathrm{A})$ (nome do paciente) teve medo relacionado com a ideia de ser responsável por algo terrível, como, por exemplo, incêndio ou roubo, ou se queixou de ver imagens violentas ou terríveis?"

\section{OBSESSÕES DE CONTAMINAÇÃO}

"Durante a última semana, o(a) (nome do paciente) apresentou preocupações excessivas ou nojo de secreções ou fluidos corporais, sujeira ou germes? Ele(a) apresentou preocupação excessiva com contaminação por toxinas do meio ambiente, asbestos (venenos), radiação ou lixo tóxico? $\mathrm{O}(\mathrm{A})$ (nome do paciente) teve medo de contaminação por alvejantes ou solventes domésticos ou por animais, como, por exemplo, insetos? Ele(a) apresentou desconforto com substâncias gosmentas ou resíduos e teve medo de contrair doença por causa da contaminação ou se preocupou em contaminar outros?" 


\section{OBSESSÕES SEXUAIS}

"Durante a última semana, o(a) (nome do paciente) apresentou obsessões envolvendo pensamentos, imagens ou impulsos sexuais impróprios ou proibidos, ou ele(a) teve pensamentos incestuosos repetidos de (fazer sexo com familiares próximos) envolvimento sexual com crianças, ou comportamento sexual agressivo em relação a outros?”

\section{OBSESSÕES DE GUARDAR/PERDER}

"Durante a última semana, o(a) (nome do paciente) teve obsessões de guardar coisas ou um medo infundado de perder alguma coisa de valor?"

\section{OBSESSÕES RELIGIOSAS}

"Durante a última semana, o(a) (nome do paciente) apresentou obsessões envolvendo pensamentos desrespeitosos, de cometer sacrilégios ou de dizer blasfêmias? Ele(a) apresentou preocupação excessiva quanto ao certo e errado?”

\section{OBSESSÕES ENVOLVENDO SIMETRIA OU EXATIDÃO}

"Durante a última semana, o(a) (nome do paciente) apresentou obsessões relacionadas à necessidade dos objetos estarem simétricos (perfeitos) ou exatamente no lugar certo? Ele(a) insiste que certos itens não sejam movidos ou tocados - por exemplo, precisa que as comidas enlatadas estejam alinhadas ou que as roupas estejam organizadas alfabeticamente (de uma certa maneira, por cor, tamanho, etc.)?"

\section{OBSESSÕES SOMÁTICAS (DE DOENÇA)}

"Durante a última semana, o(a) (nome do paciente) apresentou preocupações excessivas relacionadas com doenças (como AIDS ou câncer)?"

\section{OBSESSÕES DIVERSAS}

"Durante a última semana, o(a) (nome do paciente) demonstrou uma necessidade excessiva de saber ou lembrar, medo de perder objetos, obsessões quanto a dizer certas coisas ou não dizer exatamente a coisa certa, um desconforto com certos sons ou barulhos, ou teve pensamentos relacionados com números de sorte ou azar?”

\section{COMPULSÕES}

"Compulsões são definidas como comportamentos ou atos que a pessoa se sente pressionada a fazer, embora reconheça que são sem sentido ou excessivos. Pode ser difícil ou provocar ansiedade em uma pessoa caso ela resista a esses comportamentos."

"Agora vou revisar uma lista de diferentes tipos de compulsões comuns ao TOC. Por favor, me diga se o(a) (nome do paciente) apresentou alguma dessas compulsões durante a última semana."

\section{COMPULSÕES DE LIMPEZA/LAVAGEM}

"Durante a última semana, o(a) (nome do paciente) se envolveu de modo excessivo ou ritualizado no ato de lavar as mãos, em duchas, banhos, escovação de dentes, pentear os cabelos ou rotinas de limpeza? Ele(a) fez limpeza excessiva de itens domésticos ou outros objetos inanimados (sem vida), ou se envolveu em outras medidas para remover ou prevenir contato com contaminantes?"

\section{COMPULSÕES DE VERIFICAÇÃO}

"Durante a última semana, o(a) (nome do paciente) verificou excessivamente fechaduras, trancas, fogão, eletrodomésticos ou outros itens? Ocupou-se em verificar para confirmar que não machucou ou machucará a si mesmo ou a outros, que nada terrível aconteceu ou acontecerá, ou que não cometeu nenhum erro? O(A) (nome do paciente) realizou verificações relacionadas a medo de doenças ou contaminação?”

\section{RITUAIS DE REPETIÇÃO}

"Durante a última semana, o(a) (nome do paciente) teve de reler ou reescrever ou repetiu atividades rotineiras, por exemplo sentar e levantar de uma cadeira?"

\section{COMPULSÕES DE CONTAGEM}

"Durante a última semana, o(a) (nome do paciente) apresentou compulsões envolvendo a contagem de objetos (por exemplo, contando azulejos do piso, livros na prateleira ou palavras em uma frase)?” 


\section{COMPULSÕES DE ORDEM/ARRANJO}

"Durante a última semana, o(a) (nome do paciente) apresentou compulsões envolvendo ordenar ou arrumar objetos (por exemplo, alinhamento excessivo de papéis em uma mesa, ajustamento de móveis ou porta retratos)?"

\section{COMPULSÕES DE COLECIONAR/GUARDAR}

"Durante a última semana, o(a) (nome do paciente) se envolveu em juntar coisas (como, por exemplo, jornais velhos ou correspondência sem valor) ou colecionar outras coisas?"

\section{COMPULSÕES VARIADAS}

"Durante a última semana, o(a) (nome do paciente) se envolveu em rituais mentais, como fazer listas excessivas, medidas para prevenir danos a si mesmo ou aos outros ou prevenir consequências terríveis, ou evidenciou a necessidade de contar, perguntar ou confessar alguma coisa?"

\section{OUTROS PROBLEMAS RELACIONADOS AO TOC}

\section{EVITAÇÃO}

"Durante a última semana, o(a) (nome do paciente) evitou fazer coisas, ir a locais ou estar com pessoas por causa de pensamentos obsessivos ou devido a preocupações de que poderia realizar atos compulsivos?"

\section{INDECISÃO}

"Durante a última semana, o(a) (nome do paciente) apresentou dificuldades em tomar decisões sobre coisas que outras pessoas possivelmente não pensariam duas vezes: por exemplo, que roupas vestir de manhã ou que marca de cereal comprar?"

\section{SENSO DE RESPONSABILIDADE SUPERVALORIZADO}

"Uma pessoa com TOC pode se sentir muito responsável pelas consequências de suas ações e assumir a culpa por resultados de eventos que não estão completamente sob seu controle. $\mathrm{O}(\mathrm{A})$ (nome do paciente) exibiu um senso de responsabilidade excessiva durante a última semana?"

\section{LENTIDÃO/PERTURBAÇ̃̃O DE INÉRCIA (ficar parado)}

"Alguns pacientes com TOC têm dificuldades para começar ou terminar tarefas. Muitas atividades rotineiras levam muito mais tempo do que deveriam. $\mathrm{O}(\mathrm{A})$ (nome do paciente) teve esse tipo de dificuldade com alguma tarefa rotineira durante a última semana?"

\section{DÚVIDA PATOLÓGICA (excessiva)}

"Alguns pacientes com TOC têm dúvidas se eles fizeram uma atividade corretamente ou se de fato a fizeram. Ao realizar atividades rotineiras, podem achar que não confiam nos seus sentidos, ou seja, não acreditam no que veem, ouvem ou tocam. $\mathrm{O}(\mathrm{A})$ (nome do paciente) teve esse tipo de dúvida durante a última semana?"

\section{LISTA DE SINTOMAS DO PACIENTE}

(Descreva os sintomas relatados pelo familiar e mencione essa lista quando fizer o restante das perguntas.)

\section{$\underline{\text { OBSESSÕES }}$}

1.

2.

3.

4.

5.

6. 


\section{COMPULSÕES}

1.

2.

3.

4

5.

6.

\section{OUTROS PROBLEMAS RELACIONADOS AO TOC}

1.

2.

3.

4.

5.

6

\section{RELATÓRIO DO FAMILIAR DE COMPORTAMENTOS DE ACOMODAČ̃̃O}

INSTRUÇÕES PARA O MEMBRO DA FAMÍLIA: "Você me contou que o(a) (nome do paciente) tem os seguintes sintomas: ... (rever a lista de sintomas do paciente). Eu, agora, vou perguntar sobre as formas como você tem respondido ao(à) (nome do paciente) e aos seus sintomas durante a última semana."

(Formule exemplos de acomodação para cada pergunta usando os sintomas especificos da lista de sintomas do paciente.)

\section{PROVENDO REASSEGURAMENTO (DANDO CONFIANCCA, TRANQUILIZANDO)}

"Durante a última semana, quando o(a) (nome do paciente) demonstrou preocupação, medo ou dúvidas relacionadas a obsessões ou compulsões, você tentou tranquilizá-lo, reafirmando que ele(a) não tem que se preocupar, que não há motivos para suas preocupações ou que os rituais que já realizou resolveram suas preocupações? Exemplos podem incluir dizer ao seu familiar que ele não está contaminado, ou que ele já limpou ou verificou o suficiente.”

"Durante a última semana, em quantas ocasiões você tentou tranquilizar o(a) (nome do paciente) em razão de uma obsessão ou compulsão? (Não inclua exemplos em que você deu um apoio mais geral de que ele(a) vai superar os sintomas ou se sentir melhor logo, ou tranquilizou o(a) paciente sobre assuntos não relacionados ao TOC.)”

N/A = Não se aplica. Paciente não apresentou sintomas de TOC na última semana.

$0=$ Nenhuma

$1=1 \mathrm{vez} /$ semana

$2=2-3$ vezes/semana

$3=4-6$ vezes/semana

$4=$ Todo dia

\section{ASSISTINDO AOS RITUAIS DO PACIENTE}

"Durante a última semana, você deliberadamente (intencionalmente) assistiu à realização completa dos rituais do(a) (nome do paciente) quando ele solicitou ou porque você imaginou que ele queria que fosse assim?"

"Durante a última semana, quantas vezes você assistiu à realização completa dos rituais do(a) (nome do paciente)? (Não inclua exemplos nos quais você casualmente o viu realizando rituais.)"

N/A = Não se aplica. Paciente não apresentou sintomas de TOC na última semana.

$0=$ Nenhuma

$1=1 \mathrm{vez} / \mathrm{semana}$

$2=2-3$ vezes/semana

$3=4-6$ vezes/semana

$4=$ Todo dia 


\section{ESPERANDO PELO PACIENTE}

"Durante a última semana, você esperou que o(a) (nome do paciente) completasse os comportamentos compulsivos, resultando em interferência nos planos que você tinha feito?"

"Durante a última semana, quantas vezes você esperou pelo(a) (nome do paciente) por causa do TOC?"

N/A = Não se aplica. Paciente não apresentou sintomas de TOC na última semana.

$0=$ Nenhuma

$1=1 \mathrm{vez} / \mathrm{semana}$

$2=2-3$ vezes/semana

$3=4-6$ vezes/semana

$4=$ Todo dia

\section{CONTENDO-SE PARA NÃO DIZER OU FAZER COISAS}

"Durante a última semana, houve coisas que você não fez ou não disse por causa do TOC do(a) (nome de paciente)? Por exemplo, os familiares podem não entrar em algumas áreas da casa, não ter contato físico com o paciente com TOC, ou podem evitar falar algumas coisas relacionados às obsessões do paciente.”

"Durante a última semana, com que frequência você teve que se reprimir para não dizer ou fazer alguma coisa por causa do TOC que o(a) (nome do paciente) tem?"

N/A = Não se aplica. Paciente não apresentou sintomas de TOC na última semana.

$0=$ Nenhuma

$1=1 \mathrm{vez} /$ semana

$2=2-3$ vezes/semana

$3=4-6$ vezes/semana

$4=$ Todo dia

\section{PARTICIPANDO DAS COMPULSÕES}

"Durante a última semana, você se envolveu com as compulsões ou comportamentos que você considera estranhos ou sem sentido, porque o paciente pediu ou porque você pensou que o(a) (nome do paciente) iria querer que você fizesse essas coisas? Por exemplo, familiares podem lavar suas mãos mais vezes do que sentem ser necessário (ou de modo ritualizado), ou podem verificar os queimadores (bicos) do fogão repetidamente, mesmo que eles acreditem que os queimadores (bicos) não estão acesos."

"Durante a última semana, quantas vezes você participou diretamente dos rituais do(a) (nome de paciente), ou de comportamentos que você considera estranhos ou sem sentido?"

N/A = Não se aplica. Paciente não apresentou sintomas de TOC na última semana.

$0=$ Nenhuma

$1=1 \mathrm{vez} /$ semana

$2=2-3$ vezes/semana

$3=4-6$ vezes/semana

$4=$ Todo dia

\section{FACILITANDO AS COMPULSÕES}

"Houve vezes, na última semana, em que as suas ações tornaram possível ao(à) (nome do paciente) completar seu ritual (sem que você estivesse diretamente envolvido na facilitação dos rituais). Por exemplo, um familiar pode fornecer a um parente com TOC as coisas que ele necessita para realizar os rituais ou compulsões, tais como comprar quantidades excessivas de sabão ou produtos de limpeza. Outros exemplos: dirigir o carro de volta para que o paciente possa verificar se as portas da casa estão trancadas, ou criar um espaço extra na casa para os itens guardados do paciente.”

"Durante a última semana, quantas vezes você fez alguma coisa que ajudasse o(a) (nome do paciente) a completar os rituais? (Não incluir as situações nas quais você participou diretamente dos rituais, como observado na questão anterior (número 5).)" 


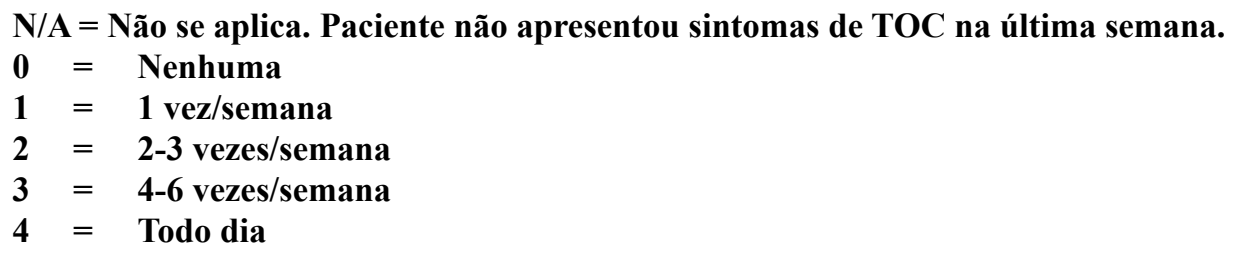

\section{FACILITANDO A EVITAÇÃO}

"Na última semana, você esteve envolvido nos esforços do(a) (nome de paciente) para evitar pessoas, lugares ou coisas? Ou você fez alguma coisa que permitiu a ele(a) evitar? Por exemplo, familiares podem dar desculpas porque o paciente diz que não pode assistir a uma situação social por causa de preocupações relacionadas ao TOC, ou fazem um desvio no trajeto de carro porque o familiar quer evitar uma área "contaminada", ou abrem uma porta para que o familiar não tenha que tocar numa "maçaneta contaminada".

"Durante a última semana, em quantas ocasiões você fez algo que ajudasse o(a) (nome do paciente) a evitar pessoas, lugares ou coisas? (Não incluir as situações nas quais você participou das compulsões ou fez algo que ajudasse seu familiar a completar as compulsões, como observado nas duas últimas questões (números 5 e 6).)”

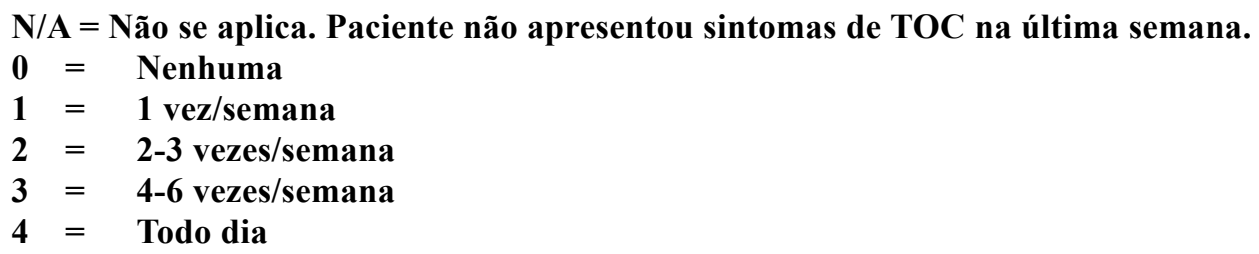

\section{TOLERANDO COMPORTAMENTOS ESTRANHOS/ROMPIMENTO DOMÉSTICO}

"Durante a última semana, você tolerou comportamentos estranhos do(a) (nome de paciente) (por exemplo, ações repetitivas como entrar e sair de uma porta), ou você tolerou condições incomuns em sua casa por causa do TOC do(a) (nome de paciente) (por exemplo, deixar a casa atravancada por jornais velhos ou ignorar o repetido fechar e abrir das portas)?"

"Durante a última semana, até que ponto você tolerou comportamentos estranhos ou condições incomuns na sua casa por causa do TOC do(a) (nome de paciente)? (Esta pergunta é específica a comportamentos ou condições que você permitiu que ocorram. Não inclua exemplos nos quais você entrou em ação para participar ou facilitar compulsões ou evitações, como observado nas três últimas questões (números 5 a 7).)" (PONTUADO PELO $A V A$ LIADOR)

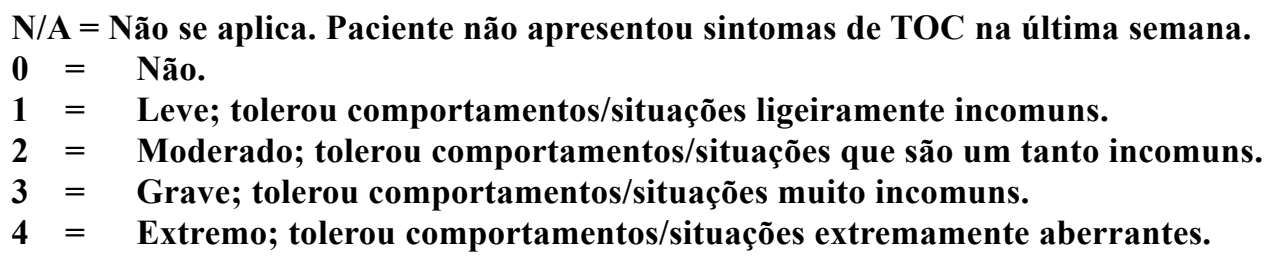

\section{AJUDANDO O PACIENTE COM TAREFAS DA VIDA DIÁRIA OU DECISÕES SIMPLES}

"Durante a última semana, você ajudou o(a) (nome do paciente) a completar tarefas simples da vida diária ou a tomar decisões simples quando a habilidade de funcionamento dele(a) foi prejudicada pelo TOC? Por exemplo, ajudar ele(a) a se vestir, se banhar ou decidir o que comer?"

"Durante a última semana, em quantas ocasiões você ajudou o(a) (nome do paciente) com tarefas ou decisões simples porque o funcionamento dele(a) estava prejudicado pelo TOC? (Não inclua situações nas quais realizar uma tarefa para seu familiar incluiu fazer algo que o ajudou a evitar um temor relacionado ao TOC (questão 7) ou nas quais tomar uma decisão para seu familiar consistiu em tranquilizá-lo sobre uma preocupação relacionada ao TOC (questão 1).)" 
N/A = Não se aplica. Paciente não apresentou sintomas de TOC na última semana.

$0=$ Nunca

$1=1 \mathrm{vez} /$ semana

$2=2-3$ vezes/semana

$3=$ 4-6 vezes/semana

$4=$ Todo dia

\section{ASSUMINDO AS RESPONSABILIDADES DO PACIENTE}

"Você assume tarefas que são de responsabilidade do(a) (nome de paciente), mas que ele(a) não pode executar adequadamente por causa do TOC? Exemplos incluem pagar suas contas ou cuidar de seus filhos."

"Durante a última semana, até que ponto você assumiu responsabilidades do(a) (nome de paciente) devido ao TOC? (Não incluir a realização de tarefas simples da vida diária para seu familiar, como observado na última questão (número 9).)" (PONTUADO PELO AVALIADOR)

N/A = Não se aplica. Paciente não apresentou sintomas de TOC na última semana.

$\mathbf{0}=$ Não.

1 Leve; ocasionalmente controla uma das responsabilidades do paciente, mas não houve nenhuma mudança significativa no papel dele.

$2=$ Moderado; assumiu as responsabilidades do paciente em uma área.

3 = Grave; assumiu as responsabilidades de paciente em mais de uma área.

4 = Extremo; assumiu a maioria ou todas as responsabilidades do paciente.

\section{MODIFICANDO SUA ROTINA PESSOAL}

"Você está atualmente modificando suas atividades de lazer, ou seu trabalho, ou responsabilidades familiares por causa do TOC do(a) (nome de paciente)? Exemplos de mudança da própria rotina incluem passar menos tempo em atividades de convívio social ou exercícios físicos (lazer), ou mudar a sua programação de trabalho para dedicar mais tempo atendendo a pessoa com TOC."

"Durante a última semana, até que ponto você modificou sua rotina pessoal por causa do TOC do(a) (nome de paciente)?" (PONTUADO PELO AVALIADOR)

N/A = Não se aplica. Paciente não apresentou sintomas de TOC na última semana.

$0=$ Não.

1 = Leve; rotina levemente modificada, mas foi capaz de cumprir com as responsabilidades da família e/ou do trabalho e de ocupar-se com atividades de lazer.

2 = Moderado; rotina definitivamente modificada em uma área (família, trabalho ou lazer).

3 = Grave; rotina definitivamente modificada em mais de uma área.

4 = Extremo; incapaz de atender às responsabilidades de trabalho ou da família ou de ter qualquer tempo de lazer devido ao TOC do paciente.

\section{MODIFICANDO A ROTINA DA FAMÍLIA}

"Você está atualmente modificando o que considera uma rotina familiar habitual devido ao TOC do(a) (nome do paciente)? Exemplos incluem alterar os hábitos de cozinhar ou de limpeza da família."

"Durante a última semana, até que ponto você modificou a rotina familiar devido ao TOC do(a) (nome do paciente)? Em que grau o TOC do seu familiar exigiu mudanças nas atividades ou rotinas da família?" (PONTUADO PELO AVALIADOR)

N/A = Não se aplica. Paciente não apresentou sintomas de TOC na última semana.

$0=$ Não.

1 Leve; a rotina familiar foi levemente modificada, mas permaneceu essencialmente inalterada.

2 = Moderado; a rotina familiar foi definitivamente alterada em uma área.

3 = Grave; a rotina familiar foi definitivamente alterada em mais de uma área.

4 = Extremo; a rotina familiar foi alterada na maior parte das áreas ou em todas elas. 